\title{
高分子のプラズマ処理における分子量変化
}

\author{
静岡大学工学部物質工学科 山谷知也・田坂 茂・稲垣訓宏
}

\section{Molecular Weight of Polymer Surfaces Treated with Low Temperature Plasma}

\author{
Tomoya Yamatani, Shigeru Tasaka and Norihiro Inagaki
}

Materials Science and Engineering, Faculty of Engineering, Shizuoka University, 3-5-1, Johoku, Hamamatsu 432-8561, JAPAN

\begin{abstract}
Melecular weight of polymer surfaces (polystylene, polyethylenetelephthalate, polyvinylchloride and ethylene/vinylacetate copolymer (75/25)) treated with low temperature Ar plasma (direct, remote and plasma-graft treatments) was measured by gel permeation chromatography. To put the information of the polymer surface, thin films with about $500 \mathrm{~nm}$ thick were employed for the measuremet. Plasma-graft polymerization using methylmethacrylate was performed after Ar plasma exposure to the films. The molecular weight depression of the polymers may proceed from the chain ends of polymers by plasma. It is found that the damaged layer depth of these polymers by ions or radicals from plasma is less than $10 \mathrm{~nm}$, and the effect of the UV is to reach to the samples deepen. Therefore, the polymers plasma-treated can be divided into two types ofcrosskining mainly by the UV and decomposing mainly by ions or radicals . Plasma-graft polymerization is effective for the polymers of the closslinking type by plasma and for the polymers of disintegrated type in the condition without the deposition of the low molecular compound reduced.
\end{abstract}

Key Words : Plasma treatment, Molecular Weight, Plasm-graft polymerization, Polymer

(Received 25 February, 1999 ; Accepted 4 April, 1999)

\section{1. 緒言}

低温プラズマは，励起分子，電子とイオンと紫外線か ら成り，物質表面に照射すると固気反応による反応層の 形成と、エッチング作用を示す。したがって高分子およ び紼維の表面改質方法の一つとしてプラズマ処理はよく 行われ，重合膜の形成，官能基の遒入，weak boundary Iayer (WBL)の除去とこれに伴う濡れ性, 接着性などの物 性向上が数多く報告されている[1,2].

たとえば高分子への不活性ガスプラズマ処理を行うと， スパッタエッチングと, crosslinking by activated speciesof inert gas(CASING) が起こるが，不活性がスであるため 官能基は導入されない。しかしながら，グラフト重合の 開始点となる主鎖型ラジカルを形成することが可能であ
る、プラズマ処理およびプラズマグラフト重合は，接着 性や濡れ性に対して結果として非常に有効であるが， 1)なぜ高分子の種類や処理ガスの種類によって大きく影 響を受けるのか，2)プラズマによって高分子がどのよう に切断またはダメージを受けるのか，3)プラズマクラフ 卜重合がどこでどのように起こるのかは明らかではない。 これらの疑問は，表面の化学組成や機能の評価はなされ ているものの分子量や密度の分布や処理深さの情報が住 とんどないことによる.

したがって本研究では，これらを明らかにすべく、プ ラズマ処理に扔ける分子量の変化を膜厚と処理条件を変 化させて議論した。ここでは表面におけるプラズマ处理 効果が強調されるよう薄膜武料を用い，また被処理高分 子もプラズマ分解型のものと架橋型のものを用いた. 


\section{2. 実験}

\section{1 高分子フィルムの作椠}

試料に，ポスチレン(以下PSと略す)，ポリエチレン テレフタレート(以下PET), エチレンービニルアセテート 共重合体(以下EVAc),およびポり塭化ビニル(以下PVC) を用いたこれらポリマーの構造をFig.1に示した. 2.5× $10 \mathrm{~cm}^{2}$ のシリコンウェハー(Sumitomo Sitix Corporation, P型)上に溶媒にテトラヒドロフラン(和光純薬工業猘),

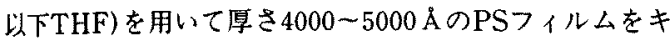
ヤス卜製膜した．PSとして，分子量 1 万と 40 万の標準 ポリスチレン(TOSOH CO.LTD製)を用いた，EVAc (三菱化学製V505, VAc25\%)，PVC(帝人侏製テビロン) についても，同様の方法でフィルムを作製した，PETに ついては，単独フィルム(東洋紡績侏製，BOPET)を用い た。

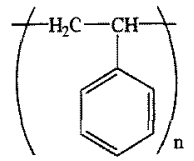

Polystytene

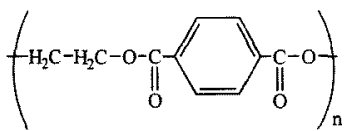

Poly(ethylene terephthalete)

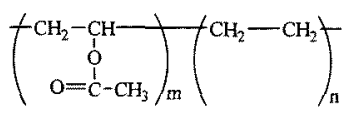

Poly(ethylene-co-vinyl acetate)

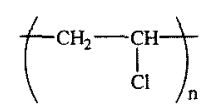

Poly(vinyl chloride)
Fig. 1 Chemical structure of PS, PVC, PET and EVAc

\section{2 アルコンンブラズマ処理}

使用したプラズマ照射装置をFig.2に示す.この装置は， 反応管, 高周波電源, 力又流量調節系, 圧量測定系, お よひ排気装置から構成される、プラズマは，高周波電源

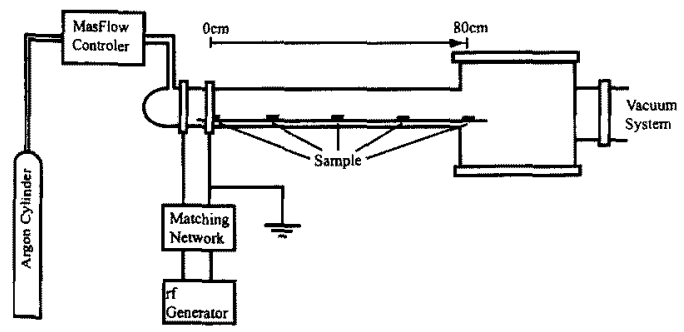

Fig. 2 Schematic diagram of remote plasma reactor (Plasma power $(13.56 \mathrm{MHz}): 30 \mathrm{~W}$, Sample position is represented by the distance from plasma induction coil)
(株式会社サムコインターナショナル研究所, RGF-200型, 発進周波数 $13.56 \mathrm{MNz}$ )を用い, 反応管外側に電極をつけ て発生させた，高分子フィルムの作製されたシリコンウ エハーを反応管内にセットし,系内の圧力を一度0.001Torr 以下に隇圧した後、アルゴンガス (帝国酸素, 純度 $99.95 \%$ ) の流量を調節しながら供給し0.1Torrとした.この状態に おいてプラズマ放電出力 $30 \mathrm{~W}$, 照射時間 30 秒から 240 秒, サンプル位置 $0 \mathrm{~cm}$ から $80 \mathrm{~cm}$ 条件でプラズマを照射した。

\subsection{GPC測定および走查里子顕微鏡(SEM)钼察}

GPC測定装置は東ソーー籼SC-8020システムを用いた。処 理した高分子フィルムをTHFまたはクロロホルム(PET) に溶かし，得た溶液の分子量分布を測定した。 なお実駼 で用いたTHFは安定唷(2,6-t-ブチルクレゾール) を含有 しているため，プラズマ照射によって主鎖または分解生 成物に発生するラジカルに分解生成物が結合し，その反 応物がGPCで測定される．そのため，ここでは安定戍の 入っていないTHFを用いてキャリブレーションを行った のちの溶出曲線を示す.

プラズマ処理した高分子フィルムと末処理フィルムの 表面形態变化の観察に走查型電子顕微鏡(侏)日立製作所製, S-2150)を使用した. 加速電圧 $10 \mathrm{kV}$, 測定角 30 度, 倍率 1000 3000倍で観察した。

\section{4 グラフト反応}

反応容器として, $250 \mathrm{ml}$ ビーカーを用いな。この反応容 器に1ープロパノール(和光純䒚工業株式会社)を溶媒とし た $10 \mathrm{vol} \%$ ×チルメタクリレート(和光純薬工業株式会社) 溶液とプラズマ照射した高分子フィルムを入れ， $60^{\circ} \mathrm{C}$ 恒 温中に窒素バブリングを行いながら一時間浸漬した，浸 漬後, 高分子フィルムを1ープロパノールで洗浄し, 残留 モノマーを除去した。

\section{3. 結果および考察}

\section{1 高分子フィルムのアルゴンプラズマ処理後の表面 観察}

ブラズマ処理によって高分子表面の形態はどう変化す るか，SEMで高分子表面の形態变化を観察した。結果を Fig.3に示す. PSでは,プラズマ処理前の試料では, 平滑 な表面で製膜時の溶媒の蒸発㾉のみが観察された。一方, プラズマ処理後の試料では処理生成物が表面に不均一に 存在し，油滴状にかたまって観察された。一方，PETは プラズマ処理前，処理後共に目立った变化は観察されな かった。

PVCはプラズマ処理前は浴媒の蒸発痕のほか, 微小な クレーターが観察された．処理後には蒸発痕は残ってい たが、クレーターはなく、平滑な表面となっていた。こ れはプラズマ照射のスパッタ効果または生成した低分子 


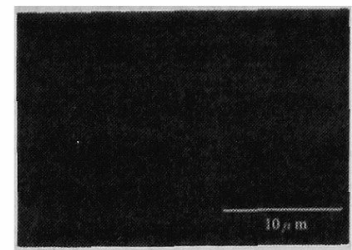

untreated PS

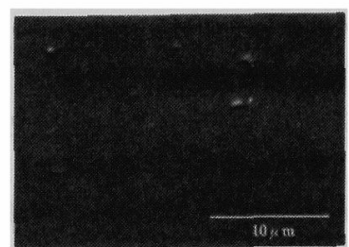

untreated PET

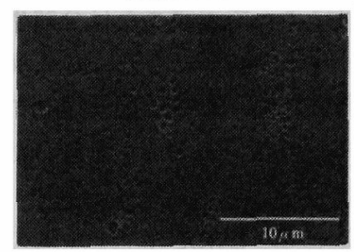

untreated PVC

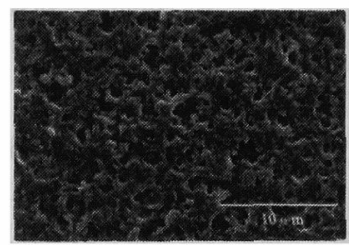

untreated EVAc

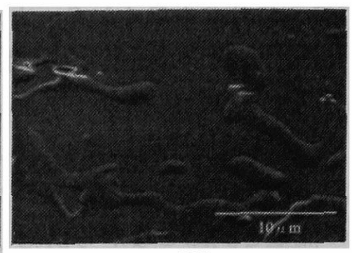

treated PS

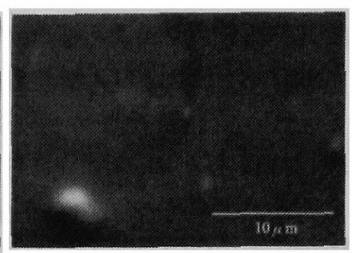

treated PET

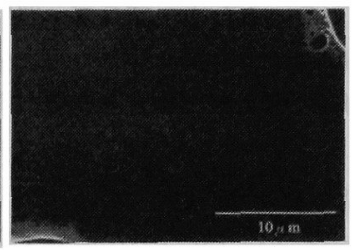

treated PVC

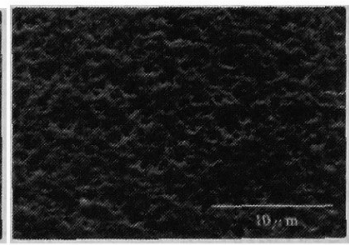

treated EVAc
Fig. 3 SEM pictures of polymer films (plasma exposure time: $30 \mathrm{~s}$, sample position: $40 \mathrm{~cm}$ )

量物が表面に堆積し，クレーターを埋めたためと考えら れる。

EVAcの表面は,フィルム作製時にEVAcが凝集すると いう現象が見られたため，他のものに比べ凹凸が激しく なった，プラズマ処理前，処理後共に凹凸が激しいが, 処理後は処理前に比べやや稳やかにになった。これは， プラズマの熱によってEVAC表面が部分融解していること が示唆される。

3.2 高分子フィルムのアルゴンプラズマ処理後の分子 量変化

分子量 1 万のPSを用いて, プラズマ発生源からの距離 を $0 \mathrm{~cm}, 80 \mathrm{~cm}$ とて 30 秒間アルゴンプラズマ処理を行っ た. そのGPC溶出曲線をFig.4に示す. 未処理の試料と比 へ，低分子側に分解生成物と思われる新しいピークが現 われた。試料の分子量は単分散ピークであり, 分解生成 物の分布も狭いことから比較的単一組成の低分子(分子量

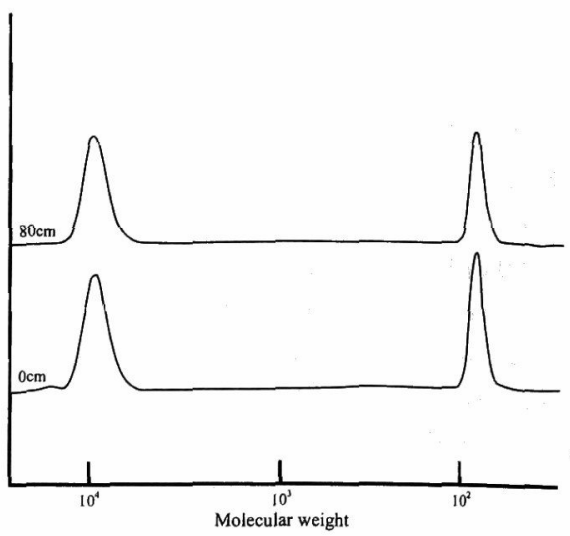

Fig. 4 GPC elution curves of PS films after argon plasma exposure as a function of sample position (plasma exposure time: $30 \mathrm{~s}$ )

80-90)であることが分かる. 分解がランタムに起こると すれば分解生成物の分子量もランダムになり，ピークか ブロードに現われると考えられる.しかし，現われた新 しいピークがシャープで分子量分布に変化がないことか ら，分子鎖の開裂がランダムではなく，高分子末端から 順に分解された低分子が婎積したものと考えられる.こ の低分子堆積物は，SEMに見られた油状物であろう。

また, サンプル位置がプラズマ発生源から遠さかると， 分解生成物のピーク面積が減少している.これは, 1)プ ラズマパワーが強い所ほど分解が促進されるか，2)アル ゴンプラズマのスパッタリング効率が場所によって異な るためにピーク面積相対比が変化した(タメージ層の厚さ はほほ一定)と考えられる。しかしながら, 溶出曲線から 得られる高分子と低分子分解物の比と膜の重量変化から 算出した低分子分解物層の見かけの厚さは,およそ $100 \mathrm{~nm}$ $150 \mathrm{~nm}$ と定であったことから，2）の理由によると考えら れる。

Fig.5にPETフィルムのアルゴンプラズマ処理後の分子 量変化を示す.PETでは未処理物にすでに低分子量物 $(660$ 程度)が含まれている. 処理によって元の高分子自体の分 子量の変化はほとんどない.しかしながら弱いプラズマ 照射を行った時にのみ低分子の分解生成物が現われた。 一般に，プラズマ発生源に近いほどスパッタリング効果 は大きい。さらにPETは, 結合エネルギーの小さいエス テル結合を持つため, スパッタリング効果はより大きく なる、そのため, サンプル位置がプラズマ発光部に近い 時には低分子量分解物は残らず, $80 \mathrm{~cm}$ と離した時にのみ 残ったと考えられる.すなわち, 分解は分子鎖の末端か ら起こるため, 強いプラズマ条件では分解物がガス化し, 表面に堆積しないと考えられる，いずれにせよ，プラズ 


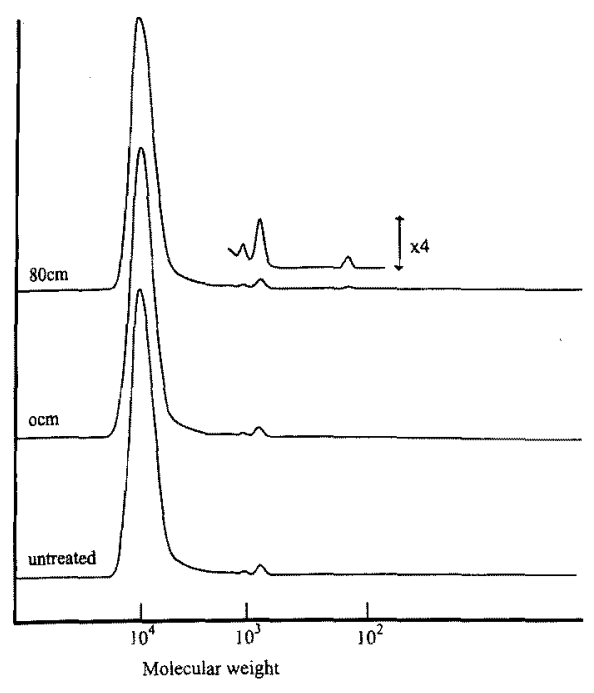

Fig. 5 GPC elution curves of PET films after argon plasma exposure as a function of sample position (plasma exposure time: $30 \mathrm{~s}$ )

マ処理によってできる分解物およびダメージ層の厚さは， 溶出曲線のピーク比から考えても非常に薄く, 数nm程度 であろう，これは高分子の慣性半径のオーダーである。

PSは末端分解型であり分解生成物がフィルム上に堆積 する夕イプで, PETは末端分解型であるが分解生成物が 紘やかな条件下を除きフィルム上に残らない夕イプだっ たいずれの場合も Tgは室温以上で表面ラジカルの拡散 は小さく，さらに芳香罱を持ち真空紫外線のダメージ 小さい. したがってプラズマの電子，イオンのダメージ は表面近傍にのみ限られていた。

次に，紫外線およひ熱的に架橋型であると考之られる PVCとEVAcについても実験した。

Fig.6にPVCフィルムのアルゴンプラズマ処理後のGPC 曲線を示す. PVCをプラズマ照射すると, 30-40\%の不溶 物(ゲル)を生じる。そのため可溶物のGPC曲線のみを示 してある. 未処理の試料にのGPC曲線に比へ，低分子量 側に新しいピークが現われる.このピークの分子量は270 である.また，試料PVCのピークの重量平均分子量を比 べると, 未処理試料が275万と16万であるのに対し，アル ゴンプラズマ処理後は 280 万と 21 万に増加している.分解 物堆積物の分子量分布はシャープで270と一定であること から，PVCの分解は，脱塩化水素と高分子鎖の末端から の分解(オリゴマー単位 (5量体))が同時進行するのである う.また, 試料PVCピークの分子量が增加していること から、架橋が起きていることがわかる，よって，PVCは 架橋分解型でありこの架橋がバルクにまでおよんでい

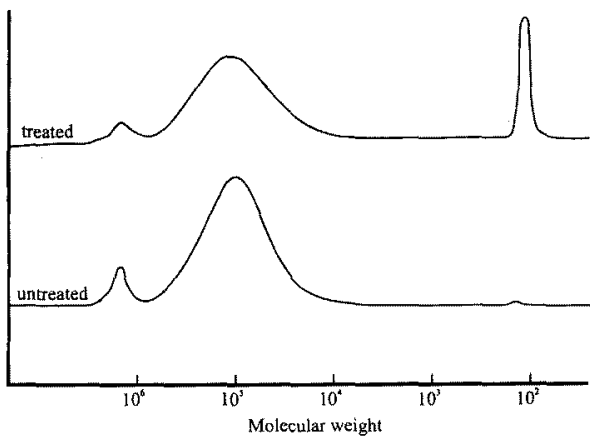

Fig. 6 GPC elution curves of the soluble part of PVC in THF after argon plasma exposure (plasma exposure time: $30 \mathrm{~s}$, sample position: $40 \mathrm{~cm}$ )

ることから，主にプラズマからでる真空紫外線によって 発生したラジカルの効果で，分解を生し，さらにイオン と電子による表面反応を生ずるのであるう.Fig.7にEVAC フィルムのアルコンンプラズマ処理後のGPC曲線を示す. サンプル位置を $40 \mathrm{~cm}$ に固定し 30 秒 240秒までアルゴンプ ラズマ処理を行った。この結果, 試料の60-70\%がゲル化 し不溶化してしまう。したがってPVCと同様, プラズマ から放射される真空紫外線の架橋効果と考えられ，GPC 測定は，THF可溶物のみに限られた，末观理試料を見る

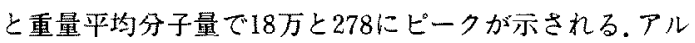
ゴンブラズマ処理後には，処理時間が240秒の試料を除い て，新しいピークは現われなかった。すなわち大部分が ゲル化しており，残留物の変化は小さい.

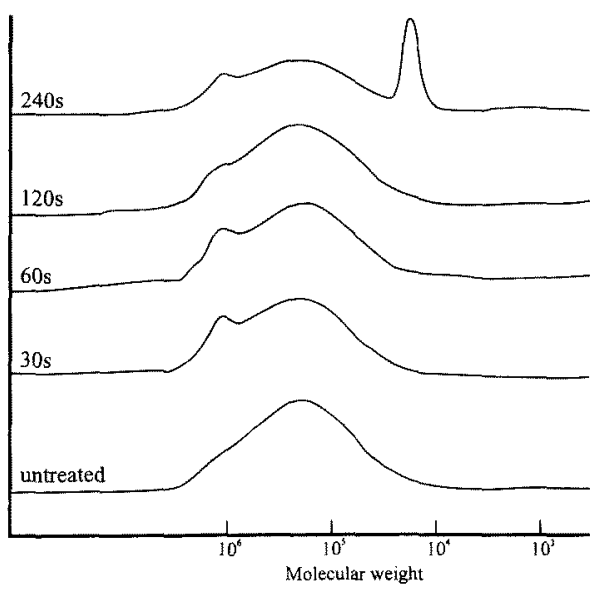

Fig. 7 GPC elution curves of the soulble part of EVAc films in THF after argon plasma exposure as a function of plasma exposure time (sample position: $40 \mathrm{~cm}$ ) 
ポリエチレン、ポリ酸酸ビニル,およびEVAC共重合体 は共にブラズマおよび紫外線架橋ポリマーに分類される [3,4]. Table 1より，処理時間が60秒までの試料につい ては分子量の增加によってTHF可溶物できえ部分架橋し, 典型的な架橋型であることが確認できた。しかし，処理 時間が 60 秒を超えると分子量の变化がプラスからマイナ スに転し，分子量が堿少していく。よって，EVAcは短時 間のプラズマ照射では架橋するが，長時間のプラズマ照 射では分解すると考えられる．Fig.7の処理時間240秒の 試料に現われた新しいピークは長時間プラズマ照射した 結果，EVAが分解したためであろう。これは通常の光反 応つまり初期には架橋，その後分解と同様なものである [5].

Table 1 Molecular weight changes of EVAc film after argon plasma exposure and its graft polymerization film

\begin{tabular}{|c|c|c|c|c|c|}
\hline & & & $\mathrm{Mn}$ & $\mathrm{Mw}$ & $\mathrm{Mw} / \mathrm{Mn}$ \\
\hline untreted & & & $5.86 \times 10^{4}$ & $1.87 \times 10^{5}$ & 3.19 \\
\hline \multirow{5}{*}{ treatment time } & $30 \mathrm{~s}$ & & $6.50 \times 10^{4}$ & $2.04 \times 10^{5}$ & 3.13 \\
\hline & $60 \mathrm{~s}$ & & $7.07 \times 10^{4}$ & $2.17 \times 10^{5}$ & 3.06 \\
\hline & $120 \mathrm{~s}$ & & $5.85 \times 10^{4}$ & $2.03 \times 10^{5}$ & 3.47 \\
\hline & $240 \mathrm{~s}$ & (peak1) & $3.38 \times 10^{4}$ & $2.01 \times 10^{5}$ & 3.69 \\
\hline & & (peak2) & $1.05 \times 10^{4}$ & $1.07 \times 10^{4}$ & 1.02 \\
\hline $\begin{array}{c}\text { after graft } \\
\text { polymerization }\end{array}$ & & & $6.92 \times 10^{4}$ & $4.25 \times 10^{5}$ & 6.41 \\
\hline
\end{tabular}

graft polymerization condition :

pre-plasma treatment, sample position $40 \mathrm{~cm}, 30 \mathrm{w}, 30 \mathrm{~s}$

graftmonomer, methylmethacryrate $\left(60^{\circ} \mathrm{C}, 1 \mathrm{~h}\right.$ in n-propanol)

\section{3 プラズマグラフト重合}

プラズマ照射によって生成する活性点(ラジカル)が高 分子中のどこに生成するのかを明らかにするためプラズ マグラフト重合を行なった、プラズマグラフト重合は, 1)プラズマによる表面ラジカルの形成，2)空気酸化によ るパーオキサイドの生成，3）ノマー存在下での熱また は光によるパーオキサイドの分解上重合開始，4）連鎖移 動，再結合に上る停止の過程で進行する。ここで我々が 分子量測定中に気付いたことは，3）過程でプラズマに よるラジカルおよび空気との接触で生成したパーオキサ イドによって基質高分子が分解する点である。すなわち 高温で長時間グラフト反応を行うと下地の高分子が分解 することが観測される，とくに分解型(崩壊)のものでは この効果が著しい，したがって今回はグラフト重合温度 時間を $60^{\circ} \mathrm{C}$, 重合時間を 1 時間と短めに設定して実験を
行った、モノマーとしてメタクリル酸メチル(以下MMA)， 溶媒にnープロパノールを用い, 処理試料は分解型のPSと 架橋型のEVAcである.

Fig.8にPSでグラフト重合を行なった時のサンプル位置 に対する分子量分布の爱化を示す。それぞれに分子量 1 万の新しいピークが現われた. PSへのプラズマ照射では， 分子量80-90の分解生成物が現かれたが，それ以外の分解 物は現われなかった：したがって，この分子量 1 万のピ 一クはMMAが重合されたことを示し、プラズマ照射され たPS中に重合開始剮となったラジカルが存在したことを 示している.また，元の分子量と分子量自体は変わらな いが分子量の分布 $\mathrm{Mw} / \mathrm{Mn}$ 1.02から1.08と広くなること から一部の高分子末端等にもPSが形成している可能性は ある。ただしの量は多くない。

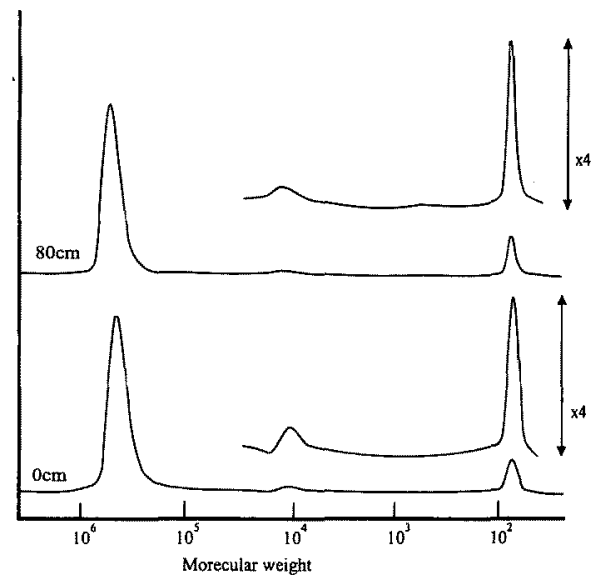

Fig. 8 GPC elution curves of plasma treated PS film $(30 \mathrm{sec}, 30 \mathrm{~W})$ after graft polymerization of MMA $\left(60^{\circ} \mathrm{C}, 1 \mathrm{~h}\right.$ in $n$-propanol) as a function of sample position

Kuzuyaら[6]は, PSにプラズマ照射して発生するラジ カルのESRスペクトル測定し，主鎖型ラジカルと cyclohexadienylタイプラジカル，そして主鎖末端型ラシ カルの生成と,主鎖型ラジカルとcyclohexadienylタイプ ラジカルは生成後すぐに架橋することを確諗している. これによると，主鎖末端型ラジカルは空気中に出すと酸 素と反応しパーオキサイドとなる。したがって，フィル ム表面に堆積している分解生成物は多くのラジカルを持 ちっこれが溶液中のMMAと反応すると一部か溶媒中に溶 け出すと同時に高分子量体は膜に堆積する。また量的に は少ないが，高分子主鎖ラジカルからもグラフト高分子 が形成するのであろう。

次にEVAcのグラフト重合後のGPC溶出曲線をFig.9に 
示寸.分子量についてはすでにTable 1に示してある.EVAc は長時間プラズマ照射すると架橋反応より分解反応の方 が多くなるため，プラズマ処理時間は30秒とした，GPC 溶出曲線( THF 可溶成分のみ) は, クラフト処理前のもの に比べブロードになり，またTable 1より Mn，Mw共に 增加することが確認できた，さらに，新しいピークは確 認されなかった，したがって，MMAがEVAc中に発生し たラジカルを開始剤としてグラフト鎖が形成したものと 考えられる。

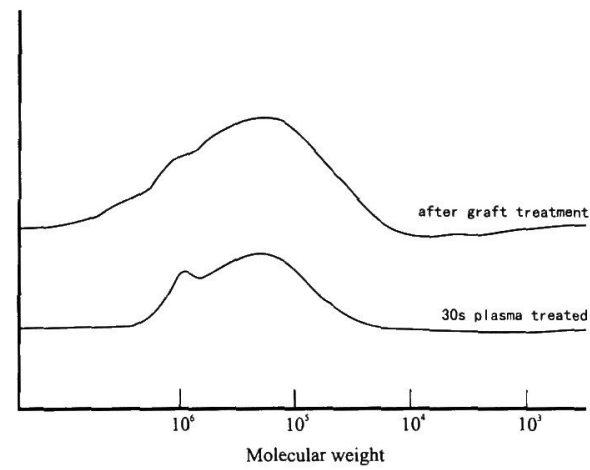

Fig. 9 GPC elution curves of plasm treated EVAc film $(30 \mathrm{~s}, 30 \mathrm{~W})$ after graft polymerization of $\operatorname{MMA}\left(60^{\circ} \mathrm{C}, 1 \mathrm{~h}\right.$ in n-propanol)

プラズマ処理における表面パーオキサイド濃度は，高 分子の種類によらずおよそ $10^{14}$ - $10^{15}$ 個/ $/ \mathrm{cm}^{2}$ である $[7,8]$. もしここにすべてポリマーが形成し，その分子量が10 ${ }^{4}$ 程度とすると，平均表面厚さはおよそ10nm程度である。 今回得られたGPCのデータからグラフト層の平均厚さを 求めると $5 \mathrm{~nm}$ 程度であった。これは短時間の重合条件であ ること，開始剤効率が低いこと，一部溶解することを考 えると良い一致と言えよう.グラフト化率を求める場合, 通常の重量測定を行うが，水などの吸着分子の影響を除 外することができなく，プラズマグラフト重合の定量的 議論が難しかった，それゆえGPCによるこの様な分析法 は非常に有効なものと考えられる。

以上のことを模式図で表わすとFig.10のようになる。 PS, PETのように分解生成物が表面に残りこれを除去す るのが難しいものでは, 多くのプラズマグラフトの開始 点が低分子となる，そのためグラフトポリマーの収率は 非常に低い，したがってこのような低分子を除去する条 件を見い出す必要がある，通常，溶剮洗浄によって低分 子は除去可能と考えられているが，実際にはポリマーの オリゴマー成分が多く，ポリマーと同一溶媒でないと除 去することが難しいようである。一方, EVAcのように架 a. Decomposition type b. Cross I ink type

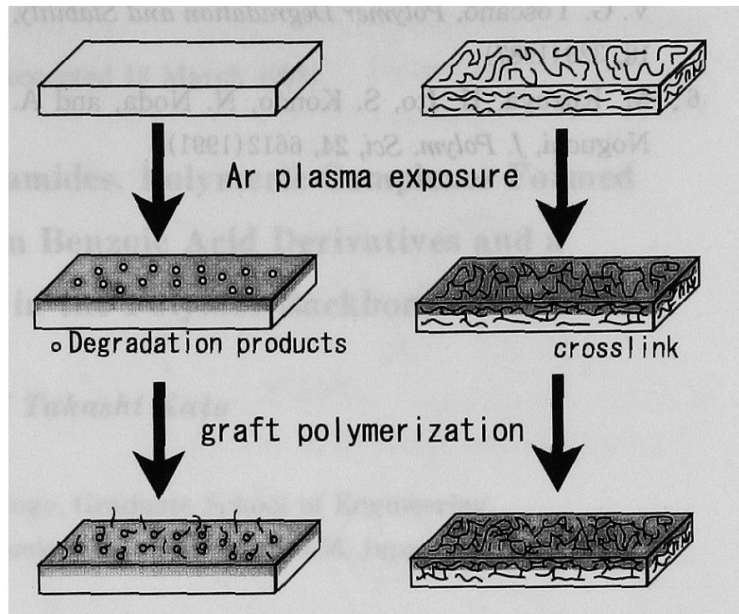

Fig.10 Schematic represetation of plasma-graft polymerization for two types of polymers ;a. Decomposition type, b. Crosslink type

橋型のものでは低分子分解物の堆積も少なく，さらに分 子末端が主鎖ラジカルとなるためプラズマグラフト重合 場として非常に有効である。

\section{4. 結 論}

1)アルゴンプラズマ照射したPS, PETの分解は末端か ら優先的に起こる，PVC注架橋と分解が同時に起こり, 分解はPS, PETと同様に主鎖の末端から分解されていく. EVAcは短時間のプラズマ照射では架橋を起こし, 長時間 プラズマ照射すると分解する.

2) プラズマ分解型高分子であるPSにグラフト重合を行 なうと表面に堆積している分解生成物のラジカルが重合 開始点となるため，高分子側にはグラフト鎖ができにく い.プラズマ架橋型高分子であるEVAcにグラフトを行な うと分解物を出さず，生成するラジカルが主鎖型ラジカ ルのみであるため，主鎖に有効にグラフト鎖を作ること ができる。

\section{文献}

1. N. Inagaki, "Plasma Surface Modification and Plasma Polymerizarion", Technomic, Lancaster (1996).

2. 長田義仁, “プラズマ重合”, 東京化学同人 (1986).

3. H. B. Olayan, H. S. Hamid and E. D. Owen, Rev. Macromol. Chem. Phys., C36, 671(1996).

4. P. V. Zamotaev, Macromol. Chem., Macromol. Symp., 28, 287 (1989). 
5. E. Y.L. Vaidergorin, M. Eunice, R. Marcondes and V. G. Toscano, Polymer Degradation and Stability, 18, 329 (1987).

6. M. Kuzuya, H. Ito, S. Kondo, N. Noda, and A. Noguchi, J. Polym. Sci, 24, 6612(1991).
7. M. Suzuki, A. Kishida, H. Iwata and Y. Ikada, Macromolecules, 19, 1804 (1996).

8. N. Inagaki, S. Tasaka and T. Inoue, J. Appl. Polym. Sci., 69, 1179(1998). 